\title{
Training and Development at Both Ends of the Workforce Continuum: Opportunities and Recommended Actions
}

Jerry W. Hedge and Jay Feldman

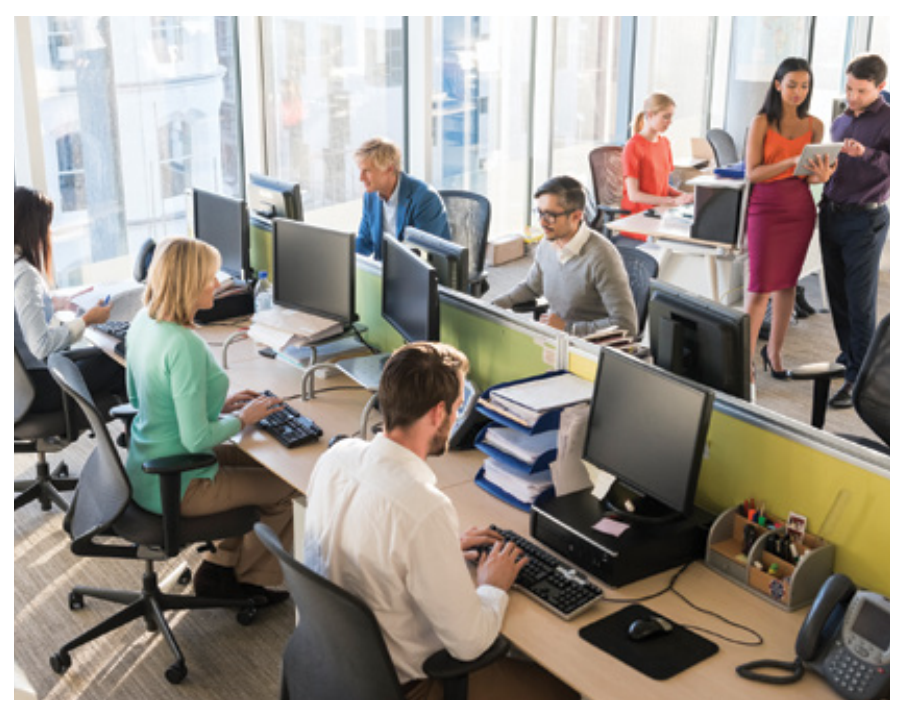

Major changes have taken place in the workplace over the last several decades and continue today. Such changes include the globalization of numerous companies and industries, organizational downsizing and restructuring, expansion of information technology use at work, changes in work contracts, and increased use of alternative work strategies and schedules. These changes have transformed the nature of work in many organizations-including the types of jobs that are available and how they are performed-creating new jobs and opportunities for employment for some and eliminating jobs and creating conditions of unemployment for others. With such changes becoming a more routine part of the work environment, institutions that offer education and training opportunities will need to re-evaluate their plans of instruction continually to insure they are targeting appropriate skill sets. Similarly, workers, in order to remain competitive, will likely need to upgrade their knowledge and skills to avoid obsolescence and learn new systems and new activities at multiple points during their working lives.

\section{Key Issues}

- High youth unemployment

- Economic conditions forcing large numbers of older workers to extend work lives

- Mismatch between academic preparation and required worker competencies

- Re-skilling of experienced workers required due to rapid technology changes

For workers of all ages, work satisfies a range of needs, including financial security, a sense of accomplishment, recognition for superior performance, skill development, and social status. However, both youths (aged 16 to 24 years old) and older workers (aged 55 years or older) often find themselves at a disadvantage in the job market. In fact, these two age groups account for nearly $50 \%$ of the unemployed labor force in the United States, and they continue to face employment hurdles associated with skills and experience deficits due to lack of training or development opportunities. This research brief focuses on the employability of youths and older workers and the important role that training and development can play in strengthening the skills of job seekers and the productivity of the workforce.

\section{Skills Development of the Youth Labor Force}

In the United States, the youth unemployment rate was more than $14 \%$ in July 2014, and has been in double-digits for the last 7 years (Bureau of Labor Statistics, 2014). During recessions and in weak job markets, youths are usually the first to be fired and the last to be hired. Subsequently, they tend to stay in school longer and experience a significant drop in labor force participation rate. Currently, these difficulties are likely to persist for youths aged 16 to 24 as they face increased competition from other age groups for the entry-level jobs they 
traditionally would fill. More than 3 million in this age group are unemployed, and many more have dropped out of the labor force altogether. In addition, there are a rising number of young people who are neither in the labor market nor in school (Jacobs, 2014).

For the most part, what separates the youths who can secure employment from those who cannot is training and work experience. Traditional academic-oriented education and training often do not adequately equip youths with the skills needed to succeed in the workplace. In fact, despite an increase in advanced degree attainment by Americans over the past 10 years, companies often struggle to find employees with the diversity and quality of skills and abilities necessary for success in a constantly evolving marketplace (ACT Foundation, 2014). For example, a recent study by the Society for Human Resource Management (SHRM Foundation, 2014) found that although a large percentage of education providers $(74 \%)$ reported confidence that their graduates' educations had prepared them well for work, only a minority of youths and employers (38\% and $35 \%$, respectively) agreed.

\section{Investing in Training and Development of Older Workers}

Older workers continue to be an essential and growing component of the workforce, with a significant proportion of late career and retirement-eligible people reporting that they will delay retirement or work in some capacity during their retirement years (see, e.g., Toossi, 2012). However, older workers in general are particularly susceptible to personnel cuts because they are often among the more highly paid employees in an organization. Once jobs are lost, older workers often face greater challenges in finding new jobs than younger workers do, because of factors such as higher current salary levels, less familiarity with job search strategies, or organizational resistance to investing in workers with fewer years left in their careers. For example, Rix (2011) found that unemployed workers aged 55 or older were the most likely of any age category to have been without a job for a year or longer and suggested that the labor market experience of older job seekers today does not bode well for their long-term employment prospects.

Although many older adults in the labor force, regardless of their current employment status, could benefit from participation in some form of re-skilling or refresher training, older workers traditionally have not been offered as many training opportunities as younger workers. Some of this may relate to stereotypic views about the learning capabilities and reluctance of older workers to seek out training opportunities, and some of this may relate to organizational thinking about return-on-investment tied to years remaining in the workforce.

\section{Learning, Training, and Development}

The life course has often been viewed as being segmented into an education-and training-for-work phase, a continuous work activity phase, and a retirement phase. The process of learning new skills and acquiring new knowledge is moving away from a strict reliance on formal education or training, no longer confined to a discrete place and time to acquire (e.g., school) and apply knowledge (e.g., the workplace). Further, the pace of technological change has implications for training - all but requiring a continuous learning philosophy on the part of individuals and organizations.

- Learning: the activity or process of gaining knowledge or skill through instruction, study, or experience.

- Training: planned efforts to foster learning among individuals or groups; activities to acquire or improve, in the short-term, jobrelated knowledge, skills, and behaviors.

- Development: a longer-term focus, emphasizing the acquisition of knowledge, skills, and behaviors that help them to advance in their career aspirations and personal interests.

\section{How Do We Ensure a Skilled Workforce?}

In the United States, the private sector has been the primary source of funds for employee training, with higher skill level and higher income workers considerably more likely to receive employer-funded training than other workers. Conversely, the federal government has been the primary source of training funds for retraining dislocated workers, training lower-skilllevel workers, and especially training new labor force entrants (Hedge \& Albright, 2013). Many training programs aimed at youths are intended to support vulnerable youths-lowincome youths and youths of color-to gain entry into the workforce. At the federal level, many of these programs have not developed into a coherent system of support, partly because programs are administered by several different agencies without coordination of activities between agencies (Fernandes-Alcantara, 2014).

Notably, regulations recently signed into law in the United States to implement the Workforce Innovation and Opportunity Act (WIOA) are intended to streamline the coordination of employment and training services, strengthen collaboration with state and local partners, and provide Americans with increased access to work-based learning, including on-the-job training and registered apprenticeships (Mauer, 2015). The law increases out-of-school youth access to pre-apprenticeship opportunities that result in registered apprenticeships, adding a requirement that a portion of funds at the local level be used on work-based training activities.

Apprenticeship training has long been associated with preparing young people to enter the labor market and continues to receive broad support in countries such as 
Germany, France, and Spain. More recently, in England and Australia, research has determined that apprenticeships directed at adults are quite effective as well (Fuller, Leonard, Unwin, \& Davey, 2015). In addition, Jackson (2013) has called for increased emphasis on apprenticeship programs in the United States (including expansion of apprenticeships in industries such as information technology, health care, and retail) as a way to develop a skilled workforce.

At the community level, many organizations are beginning to provide opportunities and incentives for youth by providing workforce readiness (employability skills) instruction along with basic skills instruction, often embedding in their programming leadership skills and values of social justice and civic engagement. Additionally, high schools have answered the call to prepare youths for either college or career pathways after high school. For example, Linked Learning programs connect strong academics with real-world experience in a wide range of fields, such as engineering, arts and media, and biomedical and health sciences. They offer students personally relevant, wholly engaging, and rigorous academic and technical curricula combined with exposure to real-world professions, preparing youths for 2- or 4-year colleges as well as apprenticeship or job training programs.

Community colleges have also become increasingly important partners in the public workforce system, training workers and job seekers through both degree and credentialing programs that help them learn basic and/or occupational skills. Government-funded partnerships between companies and community colleges have helped to ensure that job training provided by community colleges will meet the needs of employers. For U.S. workers seeking employment, credential attainment is a significant trend (Heidkamp \& Heldrich, 2012).

\section{Future Directions in Training and Development}

A new perspective on training and development must embrace the new learning framework required by the significant and accelerating changes in the nature of work and education, including the inevitability of change in the course of a professional lifetime. This philosophy focuses on developing performance-based knowledge and skill sets from a variety of learning systems and a willingness to learn new things in different ways in work settings, in postsecondary institutions, or through self-directed learning. This also requires a shift in government and industry policies toward investments in apprenticeships, paid internships, public/private training and education partnerships, and other innovative solutions (ACT, 2014; Olinsky \& Steinberg, 2013). In sum, this argues for a more competency-based education, emphasizing mastery of work-related skills rather than proficiency in a particular academic discipline (Schumpeter, 2014) and using applied, hands-on experience, whether in a classroom or on a job site, as a way to increase job preparedness.

Certainly, continuous learning and skill development by workers of all ages are becoming more important than ever before. Now all workers are increasingly being called on to learn and adapt continuously. A concerted effort will be required-by government (at all levels) and by the private sector-to underscore the need for the development and availability of training programs and career development programs designed to offer continued appropriate re-skilling, refresher training, and enriching developmental opportunities to large numbers of new and late-career workers.

Advanced training and credential attainment are increasingly encouraged so that workers will have the skills necessary to succeed in the workplace. The accelerating pace of technological changes; the transformation of the social, economic, and work environments; and changes in the technological savvy of workers of all ages contribute to underscoring the need for new and extensive research initiatives to shed light on training and development research and practice in the 21 st century.

\section{Future Directions}

- Adopt a continuous learning perspective to workforce training and development.

- Emphasize competency-based education and training.

- Encourage government and industry investments in apprenticeships, internships, and public/private education and training partnerships.

- Invest in new research initiatives to explore education and training approaches relevant for a lifelong learning framework.

Preparing youths for success in tomorrow's workforce is of increasing concern to our nation's schools, communities, policy makers, and businesses. To educate and train young people well is fundamental for allowing them to create their own future. Most workforce development programs for youths focus on acquiring the knowledge to move students into entrylevel positions, and to a lesser extent, the competencies that students should be able to demonstrate by the time they finish their coursework. Investments in career-related experiences during high school can produce substantial and sustained improvements in their labor market prospects and support their transitions to adulthood (Kemple, 2008).

Likewise, taking advantage of the expertise and institutional knowledge possessed by older workers makes good business sense. Many older workers want to continue to learn and develop the skills and talents cultivated during their careers. However, although organizations have constructed extensive 
"scaffolding" for new employees designed to orient, integrate, and develop them, career services for people beyond middle age are hard to find, despite the fact that the decisions that older people have to make are no less complex or impactful (Hedge \& Borman, 2012). A continuing desire to gain new knowledge and to develop new skills throughout the life course means the training and development enterprise has a critical role to play in the years ahead.

\section{References}

ACT Foundation. (2014). National. Learning. Economy: The NEW American dream. Retrieved from http://actfdn.org/wp-content/uploads/2014/07/ ACTFoundation_VisionPaper_Aug2014.pdf

Bureau of Labor Statistics. (2014). Employment and unemployment among youth summary. Retrieved from http://www.bls.gov/news.release/youth. nro.htm

Fernandes-Alcantara, A.L. (2014). Vulnerable youth: Background and policies (7-5700). Washington, DC: Congressional Research Service.

Fuller, A., Leonard, P., Unwin, L., \& Davey, G. (2015). Does apprenticeship work for adults? London, United Kingdom: UCL Institute of Education.

Hedge, J.W., \& Albright, V.A. (2013). Learning and training in retirement. In M. Wang (Ed.), The Oxford handbook of retirement. (pp. 476-492). New York, NY: Oxford University Press.

Hedge, J.W., \& Borman, W.C. (2012). Work and aging. In S.W.J. Kozolowski (Ed.), The Oxford handbook of organizational psychology: Volume 1 (pp. 1245-1284). New York, NY: Oxford University Press.

Heidkamp, M., \& Heldrich, J.J. (2012). Older workers, rising skill requirements, and the need for a re-envisioning of the public works system. Chicago, IL: The Council for Adult and Experiential Learning (CAEL).

Jackson, H.G. (2013). Bring back U.S. apprenticeships. HR Magazine, 58(10). Retrieved from http://www.shrm.org/publications/hrmagazine/ editorialcontent/2013/1013/pages/1013-ceo.aspx

Jacobs, E. (2014, May). Twelve ways to fix the youth unemployment crisis. Government Studies at Brookings. Retrieved from http://www.brookings. edu/research/papers/2014/05/22-youth-unemployment-crisis-workforce-jacobs

Kemple, J.J. (2008). Career academies: Long-term impacts on labor market outcomes, educational attainment, and transitions to adulthood. New York, NY: MDRC.

Mauer, R. (2015). DOL proposes rules addressing the workforce skills gap. Retrieved from http://www.shrm.org/hrdisciplines/staffingmanagement/ articles/pages/dol-rules-workforce-skills-gap.aspx

Olinsky, B., \& Ayres, S. (2013, December). Training for success: A policy to expand apprenticeships in the United States. Retrieved from http://cdn. americanprogress.org/wp-content/uploads/2013/11/apprenticeship_ report.pdf
Rix, S. (2011, May). The employment situation, April 2011: Average duration of unemployment for older jobseekers exceeds one year (AARP Fact Sheet 225). Washington, DC: AARP Public Policy Institute.

Schumpeter, J. (2014, August 23). Got skills? Retooling vocational education. The Economist. Retrieved from http://www.economist.com/news/ business/21613279-retooling-vocational-education-got-skills

SHRM Foundation (2014). What's next: Future global trends affecting your organization-evolution of work and the worker. New York, NY: The Economist Intelligence Unit.

Toossi, M. (2012). Labor force projections to 2020: A more slowly growing workforce. Monthly Labor Review, 135(1), 43-64.

\section{About the Authors}

Jerry W. Hedge, PhD, is a program director and senior research scientist in RTI's Survey Research Division. He has been involved in human resource management research and application for more than 30 years. He is currently directing the evaluation of a Trade Adjustment Assistance Community College and Career Training grant for the U.S. Department of Labor. Dr. Hedge has previously co-authored The Aging Workforce: Realities, Myths, and Implications for Organizations (2006) and co-edited the Oxford Handbook of Work and Aging (2012), as well as authoring a number of journal articles and book chapters on the topic. He is a fellow of the Society for Industrial and Organizational Psychology and the American Psychological Association.

Jay Feldman, PhD, is a senior research associate in RTI's Education and Workforce Division. He has worked for more than 20 years in social science and education research and evaluation. Trained as a developmental psychologist, he has worked in K-16 instruction, pedagogy, and curriculum; postsecondary education; informal learning environments; and youth development. Dr. Feldman is currently directing the evaluations of a Trade Adjustment Assistance Community College and Career Training grant for the U.S. Department of Labor and a number of evaluations of schools and nonprofit organizations that focus on developing youths for college and careers (including career academies, apprenticeship, and internship programs).

RTI Press Research Briefs and Policy Briefs are scholarly essays on policy, methods, or other topics relevant to RTI areas of research or technical focus.

RTI International, 3040 East Cornwallis Road, PO Box 12194 Research Triangle Park, NC 27709-2194 USA

+1.919.541.6000ｒtipress@rti.org_www.rti.org

(02015 Research Triangle Institute. RTI International is a registered trademark and a trade name of Research Triangle Institute.

All rights reserved. This brief is protected by copyright. Credit must be provided to the author and source of the document when the content is quoted. Neither the document nor partial or entire reproductions may be sold without prior written permission from the publisher.

RTI Press publication RB-0010-1508 www.rti.org/rtipress 